
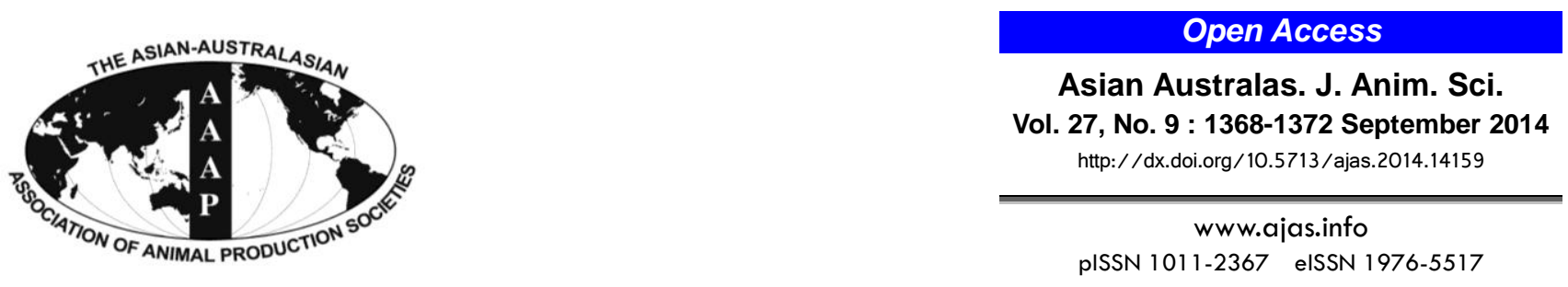

\title{
Semi-domesticated and Irreplaceable Genetic Resource Gayal (Bos frontalis) Needs Effective Genetic Conservation in Bangladesh: A Review
}

\author{
Md. Rasel Uzzaman, Md. Shamsul Alam Bhuiyan", Zewdu Edea, and Kwan-Suk Kim* \\ Department of Animal Science, Chungbuk National University, Cheongju 361-763, Korea
}

\begin{abstract}
Several studies arduously reported that gayal (Bos frontalis) is an independent bovine species. The population size is shrinking across its distribution. In Bangladesh, it is the only wild relative of domestic cattle and also a less cared animal. Their body size is much bigger than Bangladeshi native cattle and has prominent beef type characters along with the ability to adjust in any adverse environmental conditions. Human interactions and manipulation of biodiversity is affecting the habitats of gayals in recent decades. Besides, the only artificial reproduction center for gayals, Bangladesh Livestock Research Institute (BLRI), has few animals and could not carry out its long term conservation scheme due to a lack of an objective based scientific mission as well as financial support. This indicates that the current population is much more susceptible to stochastic events which might be natural catastrophes, environmental changes or mutations. Further reduction of the population size will sharply reduce genetic diversity. In our recent investigation with $80 \mathrm{~K}$ indicine single nucleotide polymorphism chip, the $F_{I S}$ (within-population inbreeding) value was reported as $0.061 \pm 0.229$ and the observed $(0.153 \pm 0.139)$ and expected $(0.148 \pm 0.143)$ heterozygosities indicated a highly inbred and less diverse gayal population in Bangladesh. Prompt action is needed to tape the genetic information of this semi-domesticated bovine species with considerable sample size and try to investigate its potentials together with native zebu cattle for understanding the large phenotypic variations, improvement and conservation of this valuable creature. (Key Words: Bangladesh, Gayal, Conservation, Semi-domestic, Genetic Resource)
\end{abstract}

\section{INTRODUCTION}

Two major independent domestication events of the auroch (Bos primigenius) subsequently formed Indian and Eurasian bovine subspecies called zebu and taurine cattle, respectively. Similarly other species of wild bovines like wild water buffalo, banteng are also domesticated. On the other hand, gaur (Bos gaurus) is the tallest and the largest extant wild bovine which is called Indian bison and that the semi-domesticated gayal (Bos frontalis) is very much related with the gaur (Giasuddin et al., 2003a). The term semi-domesticated referred to the gayal because they are only lightly domesticated and of disputed status.

The gayal belongs to the family Bovidae, tribe Bovini,

\footnotetext{
* Corresponding Author: Kwan-Suk Kim. Tel: +82-43-261-2547, Fax: +82-43-273-2240, E-mail: kwanskim@ chungbuk.ac.kr

1 Department of Animal Breeding and Genetics, Bangladesh Agricultural University, Mymensingh-2202, Bangladesh.

Submitted Mar. 3, 2014; Revised Apr. 23, 2014; Accepted Jun. 9, 2014
}

group Bovina, genus Bos and species Bos frontalis. The gayal, synonymous with mithan or mithun, is a unique bovine species which has a limited geographical distribution from east Bhutan through the Arunachal Pradesh in India to the Naga and Chin hills in the Arakan Yomarange that defines the borders between India, Bangladesh and Myanmar (Mason, 1988; Payne and Hodges, 1997).

Scientists around the world have well understood that the existing diversity, characteristics and use of indigenous animal genetic resources in developing countries is the basis for their present as well as future sustainable utilization. So, the current genetic status of indigenous animal genetic resources must be conserved and record their characteristics and genetic information before much of genetic erosion or being extinct of those species. Hopefully, there are already available platforms for worldwide domestic animal diversity information system e.g. DAD-IS (http://en. wikipedia.org/wiki/DAD-IS), DAGRIS (http://dagris.ilri. cgiar.org/default.asp) etc. Besides, there are many ongoing

Copyright $@ 2014$ by Asian-Australasian Journal of Animal Sciences This is an open-access article distributed under the terms of the Creative Commons Attribution Non-Commercial License (http://creativecommons.org/licenses/by-nc/3.0/), which permits unrestricted non-commercial use, distribution, and reproduction in any medium, provided the original work is properly cited. 
projects focusing mainly for conservation and sustainable use of indigenous livestock and wild relatives across the world, for example; UNEP-GEF-ILRI FAnGR Asia project (http://www.fangrasia.org/). The unique characteristics or specific features of an indigenous breed could therefore be treated for rational utilization as well as sustainable livestock breeding policy of present and future or of formation of a new livestock breeds with those unique merits of indigenous breeds.

In this paper, we focus on the merits of the genetic potential gayal across its distribution and address the urgent need of Bangladeshi gayal population to protect them from extinction since the population is facing a formidable situation. It has also been essential to study this breed which could be a way forward to understand more about the genetics and do more for the improvement of the livestock species in Bangladesh.

\section{APPRECIATION AND USAGE OF GAYAL}

In Naga and Chin hills, gayals are important sacrificial animals and regarded as a social status symbol for the Naga people (Simoons and Simoons, 1968). In the moist forests of these hills, gayals are free-ranging animals without planned breeding and are therefore sometimes described as semi-domestic animals (Scherf, 2000). The Naga people encourage interbreeding between wild gaur and their gayals (Scherf, 2000). On the other hand, the gayals are particularly prized for sires to interbreed with the local breeds of cows (B. indicus type) in east Bhutan and Arunachal Pradesh (Winter et al., 1984,1988; Scherf, 2000). The $F_{1}$ hybrids produced by this crossing are known as Jatsha (male) and Jatsham (female). The Jatsham is a valuable dairy stock for these people (Winter et al., 1984; Scherf, 2000), but the Jatsha is thought to have fertility problems. Because of this male infertility, the Bhutanese herders practice backcrossing the female hybrids to domestic cattle bulls for four generations (Namikawa et al., 2007). In Bangladesh, gayal is the only wild relative of domestic zebu cattle found in the Chittagong hill tract regions, predominantly in Bandarban district together with other wild animal species like jungle fowl, wild pig, and wild quail. Some tribal family rear gayal with native cattle and their cross offspring after natural mating called "Tang gaur", which was sometime found in local market. In Bangladesh this animal are mainly used as a sacrificial animal during religious festival in exchange of high price (Giasuddin and Islam, 2003b). The gayal can interbreed with domestic cattle (Bos taurus and Bos indicus) and the female offspring may be fertile, but the male offspring may not always be fertile (Simoons, 1984; Huque et al., 2001; Giasuddin et al., 2003a; Nyunt and Win, 2004; Tanaka et al.,
2004).

\section{KARYOTYPIC AND PHYLOGENETIC STUDIES REVEAL THE ORIGIN OF GAYAL}

There are two major hypotheses on the origin of the gayal: i) they were directly domesticated from wild gaur (Simoons, 1984); and ii) they were a hybrid descendant from crossing of wild gaur and domestic cattle, either $B$. indicus or B. taurus (Payne, 1970). The practice of hybridization with cattle complicates the understanding of the domestication origin and definition of gayal. Many animal taxonomists once mistook gayal as a domesticated type of Indian gaur because of their similar appearance (Ma et al., 2007).

Several researches have been conducted to elucidate the origin of gayal. Shan et al. (1980) analyzed the karyotypes of three Bos species where they observed the number, form, and configuration of gayal chromosomes were different from yellow cattle (Bos taurus) and gaur (Bos gaurus) and their numbers of chromosomes were 58, 60, and 56, respectively. There was no sub-metacentric chromosome in the euchromosomes of yellow cattle, two pairs in gaur, and one pair in gayal. However, their sex chromosomes were all sub-metacentric chromosomes. Shan et al. (1980) speculated that gayal was neither a domesticated type of gaur nor a descendant of gaur and yellow cattle. Lan et al. (1993) investigated on restriction fragment length polymorphism of mitochondrial DNA (mtDNA) of 15 Yunnan yellow cattle, two Hesitan cows, and one gayal. The results showed that the restriction type of mtDNA of gayal was the same as that of zebu, so the maternal origin of gayal had a close relationship with zebu while Y chromosome of gayal was the same with gaur. They speculated that gayal might be the descendant of male gaur and female zebu. Ma et al. (2007) analyzed cytochrome $b(C y t b)$ gene partial sequences of 12 gayals from Yunnan province having thirtythree mutations that defined four different haplotypes. The phylogenetic trees by the NJ Neighbor-Joining (NJ) and Maximum Parsimony (MP) methods supported almost the same topology and showed that gayal was not a crossbreed descendant, but an independent species of Bos from Bos indicus, Bos taurus, and Bos gaurus. In a study, Li et al. (2008) analyzed the $C y t b$ gene entire sequences (1,140 bp) of 11 gayals in Yunnan China combined with other bovine $C y t b$ sequences cited in GenBank. The phylogenetic trees of genus Bos were reconstructed by NJ and MP methods with Bubalus bubalis as outgroup there. Both NJ and MP trees demonstrated that gayals were markedly divided into three embranchments: one embranchment clustering with Bos gaurus, another clustering with Bos taurus, and the third clustering with Bos indicus. The result of phylogenetic 
Table 1. Growth performances in regard to average live weight gain $(\mathrm{g} / \mathrm{d})$ between gayal and native calves (Haque et al., 2001)

\begin{tabular}{lllllc}
\hline \multirow{2}{*}{ Age group } & \multicolumn{2}{c}{ Live weight gain $(\mathrm{g} / \mathrm{d})$} & & \multicolumn{2}{c}{ Significance } \\
\cline { 2 - 3 } \cline { 5 - 6 } & \multicolumn{1}{c}{ Gayal calves } & Native calves & & SED & Level \\
\hline Up to 3 months & $404.60 \pm 134.39(11)$ & $217.30 \pm 52.21(31)$ & & 28.4236 & $\mathrm{p}<0.001$ \\
3 to 6 months & $306.80 \pm 116.73(14)$ & $245.30 \pm 46.35(31)$ & & 24.1353 & $\mathrm{p}<0.05$ \\
6 to 9 months & $315.20 \pm 93.95(9)$ & $262.00 \pm 46.639(18)$ & & 26.7813 & $\mathrm{p}>0.05$ \\
9 to 12 months & $312.20 \pm 90.69(6)$ & $269.00 \pm 43.15(4)$ & & 49.3208 & $\mathrm{p}>0.05$ \\
\hline
\end{tabular}

SED, standard error of a difference between 2 means; SE, standard error.

Values are mean \pm SE; figures in parentheses denote number of observations.

analysis suggested that the gayal might be the domesticated form of the gaur, and a great proportion of the gayal bloodline in China was invaded by other bovine species.

Gou et al. (2010) analyzed mtDNA control region sequences of 71 samples and SRY gene sequences of 39 samples, together with the available sequences in GenBank which showed that Yunnan gayal originated from the hybridization between male Bos frontalis and female Bos taurus or Bos indicus, and that Yunnan cattle mostly originated from $B$. indicus, also containing some hybrids of male B. indicus and female B. taurus. Again, Tanaka et al. (2011) conducted a study whereby mitochondrial cytb gene of 20 gayals from Myanmar and 13 from Bhutan were sequenced to trace its maternal origin. These results demonstrated that the principal maternal origin of gayal was gaur and suggested that it was directly domesticated from gaur. Therefore, the hypothesis that the gayal was an independent bovine species (Walker et al., 1968; Shan et al., 1980; Ma et al., 2007) was not supported with the results presented by Li et al. (2008) and Tanaka et al. (2011).

\section{PHENOTYPIC TRAITS DESERVE ATTENTION IN GAYAL}

Unlike domestic cattle the large semi-domesticated gayal has a bony dorsal ridge on the shoulder and white stocking on all four legs. The color is usually black. The male gayal is darker than the female, the coat color becoming dark brown to black at maturity. Body size of gayal is much bigger than indigenous cattle of Bangladesh. In nature average body weight of mature male gayal is 600 to $700 \mathrm{~kg}$ and female 400 to $500 \mathrm{~kg}$; the daily average milk yield of gayal was found $305 \pm 30.5 \mathrm{~mL} / \mathrm{d}$ (Giasuddin et al., 2003a). Studies reported that live weight gain (LWG) up to six (6) months of age significantly differs between gayal and native cattle (Table 1). In addition, it was also found wide variations of birth weight and LWG between the male and female of different genotypes of gayal crossbred calves (Table 2).

It was reported that the reproductive profile of gayal is very close to the domestic zebu cattle of Bangladesh (Giasuddin et al., 2003a). The animal is reported to be a very hardy and capable to adjust in any adverse environmental conditions. They are rarely used for work and also used as a valuable zoo animal. In India, gayalcattle hybrids produce more milk than gayal cows. In Bhutan, the livestock breeders produce profitable hybrid offspring called "Jatsha" by crossing gayal bull with Siri cows (Bos taurus) collected from India (NRC, 1983). However, very limited information on the biology of gayals is available.

\section{HOW THE CURRENT POPULATION IS UNDER THREAT}

Gayals abounded in the hill districts of Bangladesh but their number has diminished sharply due to human intervention. Gayals usually stay inside the forest during the daytime but venture into human habitations in search of salt and water at night. Salt is one of the most favorite food items for these animals, which is the reason the villagers often use salt to trap them. Moreover, sometimes the hill tribes collect them from the dense forest and domesticate these animals. Human interactions and manipulation of biodiversity affected the habitats of gayals and forced them to migrate into deeper forests in the further east towards the south-eastern border of the country. An artificial reproduction center for gayals was set up in Naikhangchhari of Bandarban district in 1990 under Bangladesh Livestock Research Institute (BLRI). The center started its activities with two bulls and few female gayals. So far studies reported physical feature, physiological characters, behavior, growth pattern and reproductive potentials of gayal under semi-intensive management system (Giasuddin et al., 2003a;

Table 2. Live weight gain (g/d) of gayal-cattle crossbred calves (up to 1 year) (Haque et al., 2001)

\begin{tabular}{|c|c|c|c|c|c|}
\hline Type & Genotype & $\begin{array}{l}\text { Birth weight } \\
(\mathrm{kg})\end{array}$ & $\begin{array}{l}\text { Live weight } \\
\text { at } 6 \text { months }(\mathrm{kg})\end{array}$ & $\begin{array}{l}\text { Live weight } \\
\text { at } 1 \text { year }(\mathrm{kg})\end{array}$ & $\begin{array}{l}\text { Live weight } \\
\text { gain }(\mathrm{g} / \mathrm{d})\end{array}$ \\
\hline Crossbred female & $50 \%$ Gayal $\times 50 \%$ Friesian & 36.0 & 165 & 226 & 701 \\
\hline Crossbred male & $50 \%$ Gayal $\times 50 \%($ Friesian $\times$ Friesian $\times$ Hariana $)$ & 34.0 & 113 & 177 & 437 \\
\hline Crossbred male & $50 \%$ Gayal $\times 50 \%$ Jersey & 28.0 & 128 & 212 & 556 \\
\hline
\end{tabular}


Table 3. MAF distribution at variable shared ranges of allelic proportion across the genome in gayal $(\mathrm{n}=17)$

\begin{tabular}{|c|c|c|c|c|c|c|c|c|c|}
\hline \multicolumn{10}{|c|}{ MAF categories } \\
\hline \multirow{2}{*}{\multicolumn{2}{|c|}{ Fixed (0) }} & \multirow{2}{*}{\multicolumn{2}{|c|}{$\frac{\text { Rare }}{(>0 \text { and }<0.05)}$}} & \multirow{2}{*}{\multicolumn{2}{|c|}{$\begin{array}{c}\text { Intermediate } \\
(\geq 0.05 \text { and }<0.10)\end{array}$}} & \multirow{2}{*}{\multicolumn{2}{|c|}{$\begin{array}{c}\text { Common } \\
(\geq 0.10 \text { and } \leq 0.50)\end{array}$}} & \multirow{2}{*}{\multicolumn{2}{|c|}{$\geq 0.30$ and $\leq 0.50$}} \\
\hline & & & & & & & & & \\
\hline SNP & Prop. & SNP & Prop. & SNP & Prop. & SNP & Prop. & SNP & Prop. \\
\hline 14287 & 19.00 & 15209 & 20.2 & 19141 & 25.5 & 21159 & 28.1 & 5390 & 7.2 \\
\hline
\end{tabular}

MAF, minor allele frequency; SNP, single nucleotide polymorphism; Prop., proportion.

Giasuddin and Islam, 2003b). BLRI had also undertaken gayal conservation and improvement program to develop beef type cattle for Bangladesh and to utilize the vast unused hilly areas (Huque and Giasuddin, 1998). Although initial information of the center was really encouraging, the center could not carry out its long term stable conservation scheme due to lack of financial support. A recent study reported that the herd was infected with brucellosis and the present stock will not serve the purpose of conservation of this genetic resource (Mohanta and Bhuiyan, 2010). Therefore, researchers strongly recommended that this infected herd should immediately be replaced by infectionfree animals for future conservation. Being considered the facts above and subsequently, the current population is much more susceptible to stochastic events which might be natural catastrophes, environmental changes or mutations. Experts, therefore, would like to caution that unless proper initiatives are taken to preserve gayals, these nearly extinct animals are heading for further extinction. Deforestation, pouching and illegal hunting aggravate the reasons of extinction. Unfortunately, besides the initiatives of BLRI, no other government, semi-government and NGOs has yet taken any program for the conservation of this valuable genetic resource. When the population of a species is small to begin with, further reduction of their remaining numbers will sharply reduce genetic diversity. So, urgent action is needed to conserve gayal.

\section{TOOLS FOR GENETIC EVALUATION AND SET UP CONSERVATION STRATEGY}

Effective tools have to conserve genetic potential of endangered species gayal as well as learning about it in a scientific manner. High-density single nucleotide polymorphism (SNP) arrays are now available for important farm animals and as part of our investigation we collected 17 samples of gayal along with 28 samples of indigenous zebu cattle red Chittagong (RC) from Bangladesh and genotyped with the GeneSeek Genomic Profiler Indicine HD Beadchip, an Illumina Infinium array consisting of nearly 80,000 SNPs derived mainly from Bos indicus breed (GeneSeek, Lincoln, NE, USA). For minor allele frequency (MAF) estimation, we analyzed about 69,903 autosoaml SNP markers. The MAF and proportion of polymorphic SNPs were estimated using the Golden Helix SNP Variation
Suite software version 7 (Golden Helix, 2013). The SNPs were screened based on the criteria of call rate $\geq 95$, MAF of $\geq 5 \%$ and Hardy-Weinberg equilibrium (HWE) $\geq 0.001$ which results in 51,366 SNPs. Within breed genetic variability (observed and expected heterozygosity) and inbreeding (Weir, 1996) estimates were calculated using PowerMarker V3.25 software (Liu and Muse, 2005). Minor allele frequency distribution across the genome of gayal is shown in Table 3. Our initial analysis of $80 \mathrm{~K}$ chip data revealed that the existing gayal population is in less diverse and highly inbred status. The observed and expected heterozygosities were $0.153 \pm 0.139$ and $0.148 \pm 0.143$, respectively. The inbreeding coefficient was found $0.061 \pm 0.229$ in our sampled gayal population.

So, tapping the genetic information of this semidomesticated bovine species is indeed a timely approach by us especially considering the value and importance of this genetic resource. Side by side we need to take an initiative for looking into the genome wide diversity having more samples and together with the zebu cattle in Bangladesh. The comparative diversity study might lead to know the genes under selection between these two species. There might also be possible to study the molecular variants of candidate genes in these species and that could give a hint of large phenotypic variations specifically for economic, adaptive as well as fitness traits between cattle and gayal. In addition, this study would help in genetic evaluation and artificial selection of the animals for future generations and/or synthetic breed development in Bangladesh. The investigation therefore, could open up new horizons for research regarding conservation of farm animal's genetic resources like sheep, goat, buffalo etc. that will aid a lot in boosting production potential of these species.

\section{ACKNOWLEDGMENTS}

This study was supported by a MOU between Chungbuk National University and Bangladesh Agricultural University and Next-Generation BioGreen 21 Program under Rural Development Administration.

\section{REFERENCES}

Giasuddin, M., K. Huque, and J. Alam. 2003a. Reproductive potentials of gayal (Bos frontalis) under semi-intensive 
management. Asian Australas. J. Anim. Sci. 16:331-334.

Giasuddin, M. and M. Islam. 2003b. Physical feature, physiological character and behavior study of gayal (Bos frontalis). Asian Australas. J. Anim. Sci. 16:1599-1603.

Golden Helix, I. 2012. SNP \& Variation Suite Manual, Version 7.6.9. Available at: http://www.goldenhelix.com Accessed April10, 2012.

Gou, X., Y. Wang, S. Yang, W. Deng, and H. Mao. 2010. Genetic diversity and origin of Gayal and cattle in Yunnan revealed by mtDNA control region and SRY gene sequence variation. J. Anim. Breed. Genet. 127:154-160.

Huque, K. and M. Giasuddin. 1998. Development of beef cattle breed using gayal. Animal Production Research Division, Bangladesh Livestock Research Institute, Savar, Dhaka, Bangladesh.

Huque, K. S., M. M. Rahman, and M. A. Jalil. 2001. Study on the growth pattern of gayals (Bos frontalis) and their crossbred calves. Asian Australas. J. Anim. Sci. 14:1245-1249.

Lan, H., X. Xiong, S. Lin, A. Liu, and L. Shi. 1993. Mitochondrial DNA polymorphism of cattle (Bos taurus) and mithun (Bos frontalis) in Yunnan Province. Acta genetica Sinica 20:419-425.

Li, S. P., H. Chang, G. L. Ma, H. Y. Chen, D. J. Ji, and R. Q. Geng. 2008. Molecular phylogeny of the gayal inferred from the analysis of cytochrome $b$ gene entire sequences. Hereditas 30:65-70.

Liu, K. and S. V. Muse. 2005. PowerMarker: an integrated analysis environment for genetic marker analysis. Bioinformatics 21:2128-2129.

Ma, G., H. Chang, S. Li, H. Chen, D. Ji, R. Geng, C. Chang, and Y. Li. 2007. Phylogenetic relationships and status quo of colonies for gayal based on analysis of Cytochrome $b$ gene partial sequences. J. Genet. Genomics 34:413-419.

Mason, I. L. 1988. World Dictionary of Livestock Breeds. 3rd edn. CAB International, Wallingford, CT, USA.

Mohanta, U. and A. Bhuiyan, A. 2010. Proceedings of the annual research review workshop. Bangladesh Livestock Research Institute, Savar, Dhaka, Bangladesh.

Namikawa, T., T. Dorji, M. Kurachi, T. Yamagata, Y. Kurosawa, and Y. Yamamoto. 2007. The traditional cattle breeding systems in Bhutan: genetic implication in the hybrid production process. Rep. Soc. Res. Native Livest. 24:61-68.
NRC. 1983. Little-known Asian animals with a promising economic feature. National Academy Press, Washington DC, USA. pp. 21-26.

Nyunt, M. and N. Win. 2004. Mithan (Bos frontalis) in Myanmar. Rep. Soc. Res. Native Livest. 21:19-22.

Payne, W. J. A. 1970. Cattle Production in the Tropics. Vol. I. Breeds and Breeding. Longman Group Ltd.., London, UK.

Payne, W. J. A. and J. Hodges. 1997. Tropical Cattle: Origins, Breeds and Breeding Policies. Blackwell Science, City, Country.

Scherf, B. D. 2000. Word watch list for domestic animal diversity. 3rd ed. Food and Agriculture Organization of the United Nations, Rome.

Shan, X. N., Y. F. Chen, L. H. Luo, X. M. Cao, J. Z. Song, and Y. Z. Zeng. 1980. The karyotype analysis of gayal. Hereditas (Beijing) 2:25-27.

Simoons, F. and E. Simoons. 1968. A ceremonial ox of India: the mithan in nature, culture, and history, with notes on the domestication of common cattle. The University of Wisconsin Press, Madison, WI, USA.

Simoons, F. J. 1984. In: Evolution of Domesticated Animals. Longman, London, UK. pp. 34-39.

Tanaka, K., H. Mannen, Y. Kurosawa, K. Nozawa, M. Nishibori, Y Yamamoto, H. Okabayashi, K. Tsunoda, T. Yamagata, and Y. Suzuki. 2004. Cytogenetic analysis of mithan in Myanmar. Rep. Soc. Res. Native Livest. 21:123-127.

Tanaka, K., T. Takizawa, H. Murakoshi, T. Dorji, M. M. Nyunt, Y. Maeda, Y. Yamamoto, and T. Namikawa. 2011. Molecular phylogeny and diversity of Myanmar and Bhutan mithun based on mtDNA sequences. Anim. Sci. J. 82:52-56.

Walker, E., F. Warnick, and S. Hamlet. 1968. Mammals of the world. The Johns Hopkins Press, Balttmore, MD, USA.

Weir, B. 1996. Genetic Data Analysis II. Sinauer Associates, Sunderland, MA, USA.

Winter, H., M. Kalat, B. Mayr, E. Dworak, and W. Schleger. 1988. Mithun cross siri hybrids: Cyto- and immunogenetic examinations and characterization of abnormal spermatogenesis. Res. Vet. Sci. 45:86-100. 